\title{
Banking (on) Different Forms of Symbolic Capital
}

Blaise Cronin and Debora Shaw, School of Library and Information Science, Indiana University, Bloomington, IN 47405-1901, USA

[bcronin;shawd]@indiana.edu

The accrual of symbolic capital is an important aspect of academic life. Successful capital formation is commonly signified by the trappings of scholarly distinction or acknowledged status as a public intellectual. We consider and compare three potential indices of symbolic capital: citation counts, web hits, and media mentions. Our findings, which are domain-specific, suggest that public intellectuals are notable by their absence within the information studies community.

\section{Introduction}

Validity and reliability concerns notwithstanding, citations are widely used as indicators of, or proxies for, intellectual influence and impact (Cronin, 1981)—and also viewed as expressions of social trust (Davenport \& Cronin, 2000). More particularly, a variety of studies has shown that rates of return to citation are substantial in the context of the academic reward system, with its emphasis on the accumulation of symbolic capital—distinctions, prizes, promotions, professional reputation, etc. (Cronin, 1996). Pierre Bourdieu (1990, p. 76) has referred to citations as the "most objectified of the indices of symbolic capital," while Nelson (1997, p. 39) has likened them to "academia's version of applause.” Cronin (2000, p. 450), in turn, has described the "transvaluation of these stockpiles of manipulated and manipulable capital into objectified ratings and rankings." Within the political economy of academia, citations are a highly regarded form of symbolic capital; in the vernacular, you can bank on citations. This, of course, is not to say that such indices of perceived intellectual worth are unproblematic, as Bourdieu $(1986,1990,1991)$ and others (e.g., Sosternic, 2000) have noted, nor to underestimate the complexity of discursive practice—of which citation is an important facet—within scholarly communities (e.g., Budd, 2001; Hyland, 2000).

With the advent of the Web, we now have new ways of tracking scholars' visibility, both within and beyond their traditional spheres of influence. In an early discussion of web-derived indicators of scholarly salience, Cronin et al.. (1998, p. 1326) made the following point: "While traditional citation analysis can tell us a lot about the formal bases of intellectual influence, it, quite naturally, tells us nothing 
about the many other modalities of influence which comprise the total impact of an individual's ideas, thinking and general professional presence.” They went on to say (p. 1326), “[t]he range of genres of invocation made possible by the Web should help give substance to modes of influence which have historically been backgrounded in narratives of science..." To demonstrate their point, they developed an inductive typology of web-based invocations to cover the full range of mentions (from a simple listing of one's name as a faculty member, through inclusion of one's textbook on a course syllabus, to being the center of a serious scholarly discussion on a listserv) based upon the form or context in which the mentions occurred. The eleven categories were: abstract, article, conference proceedings, current awareness, external home page, listserv, personal/parent organization home page, resource guide, book review, syllabus, table of contents. Of course, receiving a mention—or making a splash—on the Web is not quite the same thing as being cited by one's academic peers in a refereed journal or scholarly monograph: the diversity of the Web audience, along with the broader repertoire of possible forms of invocation and associated motivations, calls for interpretative caution. Specifically, the population of potential 'citers' on the web is broader than one's habitual, or even extended, scholarly audience. The Web provides a means for those beyond the traditional discursive pale to both receive and react to ideas once corralled within the formal scholarly literature. It also provides academics with the means of reaching a wider audience, well beyond their immediate institutions and disciplines. Thus, one needs at the very least to distinguish between, on the one hand, enduring scholarly impact—as suggested by a cumulating citation record—and, on the other, web-based measures of "street cred" (Cronin, 2001, p. 6) or "transient group interest ... a digital-age equivalent of Andy Warhol's fifteen minutes of fame for web-present authors” (Cronin, 1999, p. 954). That said, it would be perverse to preclude web-derived measures of impact, celebrity, or esteem from consideration. Some emerging indicators of online recognition and recommendation may, in time, prove to be very bankable forms of symbolic capital.

Posner (2001, p. 167) has argued persuasively that web hits and media mentions can be used conjointly as proxies for "public-intellectual status." Building on an earlier study of legal scholars as public intellectuals (Landes \& Posner, 2000), he undertook a comparison “of a public intellectual's academic renown, as proxied by the number of scholarly writings, to his celebrity as a public intellectual, as proxied by media mentions" (p. 169). For the first measure he used citation scores based on ISI's citation indexes; 
for the latter he relied on both web hits and mentions in LexisNexis general news sources. Posner used a large, heterogeneous sample $(\mathrm{N}=546)$ drawn from all walks of academic and public intellectual life (e.g., Hannah Arendt, Allan Bloom, William F. Buckley, Umberto Eco, Milton Friedman, Stephen Jay Gould, Conor Cruise O’Brien, Susan Sontag, Lionel Trilling, Edward Wilson). Moreover, he meticulously documented his data collection and analysis methods (pp. 188-193) and has made the entire dataset freely available on the Web to interested researchers (see: http://home.uchicago.edu/ posner/).

It has been suggested (Cronin, in press) that within the library and information science (LIS) field there are few if any spokespersons or public intellectuals who "contribute influentially to national debates on the issues of the day, whose pronouncements, oracular or otherwise, help shape public opinion." We decided to test that rather unflattering claim by employing Posner's approach on a relatively small and homogeneous population of scholars (no dead Germans were included), one with which we are both familiar. To the best of our knowledge, this is the first study of its kind using Posner's approach to focus on a single disciplinary population, viz., information studies. We do not claim that our results are generalizable to other academic domains.

\section{Methods}

We started with the list of the 25 most frequently cited professors generated by Budd (2000, p. 237) in his six-year study of U.S. LIS faculty productivity. Using Google (the search engine favored by Posner) we gathered the total number of Web hits for each of the 25 individuals. Our approach and sampling method, which were designed to eliminate false drops as far as possible, are described in detail in Appendix 1. Again following Posner's lead, we searched LexisNexis files (major newspapers, magazines and journals, and transcripts) for the previous five years to generate media mentions for the 25 individuals. The specifics of that search strategy are detailed in detail in Appendix 2.

\section{Results and Discussion}

Table 1 shows the three sets of measures: citation counts (ISI), Web hits (Web), and media mentions (LexisNexis); there is considerable variability. The range on the first measure is 102 to $673 ; 123$ to 18,520 on the second, and 0 to 310 on the third. Every one of these professors has a web presence, but 
nine individual have no media mentions to their credit. [As it happens, five of the six authors who were included in Cronin et al's 1998 study also featured in the present analysis, so it is reasonable to assume that the kinds of invocations identified in the former find their echo in the present study.] The data are graphed in Figure 1. One individual, Hal Varian, stands head and shoulders above the rest (see also the rankings in Table 2); quite simply, he plays in a different league, being heavily invoked and quoted. It should be noted, however, that Varian had developed a reputation as a noted economist before his appointment as dean of the School of Information Management and Systems at UC Berkeley. If we eliminate Varian, the three distributions flatten dramatically. The new top web rank goes to Rob Kling, doyen of social informatics, who left UC Irvine's Department of Computer and Information Science to take up a position at Indiana University's School of Library and Information Science in the mid-1990s. This career arabesque does not seem to have harmed either his web or media presence, on both of which he ranks higher than virtually all the native LIS faculty. (Kling's true citation score, by the way, would have been higher but for the fact that he was not affiliated with an LIS program for some of the years included in Budd's analysis; Varian may have been disadvantaged in like fashion.) With Varian removed from the frame, the third column is spare, with only two individuals (Cronin and Tenopir) managing to reach double digits. By way of illustration, media mentions included Christine Borgman on the use of FaceTrac surveillance technology at the Super Bowl, Nancy Van House on the closing of the UC Berkeley library school, and congressional testimony presented by Charles McClure.

The correlations between the three measures are shown in Table 3. The strongest correlation (0.96) is between web hits and media mentions, while those for citation counts with Web hits and media mentions are 0.69 and 0.66 , respectively. These correlation coefficients are much higher than those obtained by Posner (2001, p. 217), due, in part, we suspect, to the disciplinary homogeneity of our sample.

\section{Conclusions}

The world of citation is the closed world of the clerisy; we trade citations with other scholars, not with the public-at-large. The world of the Web, by contrast, is more open and egalitarian in character (equal opportunity invocation, if you will); here we are mentioned/linked to by our peers, but also, on occasion, by practitioners and, indeed, sundry others who may have a special or passing interest in some of the issues we 
address in our lives as academics and/or public intellectuals. The Web extends the discursive space within which scholars operate. What these polyvalent invocations mean in aggregate, or individually, is another matter (Cronin et al., 1998), and it is doubtful if, unprocessed and unwinnowed, they should be included among the battery of partial indicators conventionally used to evaluate scholarly production and impact. The media world is anything but closed (hence, presumably, the very strong positive correlation we found between the Web and media indicators); it is here, if we are lucky, that we amass celebrity capital through our strategically placed sound bites and on-tap expertise.

Regrettably, our data — the aggregate media mentions—-seem to support the assertion that there are no outstanding public intellectuals in the LIS field; whether that is a function of our collective diffidence or an expression of the media's/public's estimation of our worth is an open question, one requiring comparative analyses of different disciplinary and professional groups. What we can say with some assurance is that the supposedly leading scholars in LIS are unseen and unheard in the public sphere; unlike some other disciplines (e.g., law, whose public faces include notables such as Dershowitz, MacKinnon, Posner, Strossen, Tribe), the LIS field is has still to bring forth, to use the prevailing terminology, its first bona fide "academostar" (Spurgin, 2001) or public intellectual. It can, of course, be countered that there may be other, less visible, scholars within the ranks who have a public presence, but, having checked several well-known names not included on Budd's list for good measure, we find it hard to think who those individuals might be.

\section{Acknowledgement}

We are grateful to an anonymous referee for helpful comments.

\section{References}

Bourdieu, P. (1986). The forms of capital. In: Richardson, J. (Ed.). Handbook of theory and research for the sociology of education. New York: Greenwood Press, 241-258.

Bourdieu, P. (1990). Homo academicus [P. Collier, Trans.]. Cambridge: Polity Press.

Bourdieu, P. (1991). Language and symbolic power. [G. Raymond \& M. Adamson, Trans.] Cambridge, MA: Harvard University Press.

Budd, J. M. (2000). Scholarly productivity of U.S. LIS faculty: An update. Library Quarterly, 70(2), 230- 
245.

Budd, J. M. (2001). Instances of ideology in discursive practice: implications for library and information science. Library Quarterly, 71(4), 498-517.

Cronin, B. (1981). The need for a theory of citing. Journal of Documentation, 37(1), 16-24.

Cronin, B. (1996). Rates of return to citation. Journal of Documentation, 52(2), 188-197.

Cronin, B. (1999). The Warholian moment and other proto-indicators of scholarly salience. Journal of the American Society for Information Science, 50(10), 953-955.

Cronin, B. (2000). Semiotics and evaluative bibliometrics. Journal of Documentation, 56(4), 440-453.

Cronin, B. (2001). Bibliometrics and beyond: Some thoughts on web-based citation analysis. Journal of Information Science, 27(1), 1-7.

Cronin, B. (In press). Celebrity-challenged. In: Cronin, B. Pulp friction. Lanham, MD: Scarecrow Press.

Cronin, B., Snyder, H. W., Rosenbaum, H., Martinson, A., \& Callahan, E. (1998). Invoked on the Web. Journal of the American Society for Information Science, 49(14), 1319-1328.

Davenport, E. \& Cronin, B. (2001). The citation network as a prototype for representing trust in virtual environments. In: B. Cronin \& H. B. Atkins (Eds.). The web of knowledge: A Festschrift in honor of Eugene Garfield. Medford, NJ: Information Today, Inc. ASIS Monograph Series, 517-534.

Hyland, K. (2000). Disciplinary discourses: Social interaction in academic writing. Harlow: Pearson Education Limited.

Landes, W. M. \& Posner, R. A. (2000). Citations, age, fame, and the Web. Journal of Legal Studies, 29(319), 329-341.

Nelson, C. (1997). Superstars. Academe, 87(1), 38-54.

Posner, R. A. (2001). Public intellectuals: A study of decline. Cambridge, MA: Harvard University Press. (Chapter 5, in particular). 
Sosteric, M. (1999). Endowing mediocrity: Neoliberalism, information technology, and the decline of radical pedagogy. Radical Pedagogy, 1(1). Available at: http://www.icaap.org/iuicode?2.1.1.3

Spurgin, T. (2001). The Times Magazine and the academic megastars. The Minnesota Review, 52-54, $225-$ 238. 


\section{Appendix 1 - Web Hits Search}

We entered each subject's name as a string search using the Google search engine; searches were conducted February 23, 2002. Name variants were ORed and submitted in quotation marks, last-first, firstlast, and first-middle initial-last (e.g., "hal varian" or "varian hal" or "hal r varian"). The number of "results" calculated by Google was recorded; it should be noted that with large numbers of results Google omits items it judges "very similar" to those it displays. We recorded the total number of results, then examined $20 \%$ of the those presented (every fifth page) to ascertain the percentage of the results that correctly identified the subject of the search. The total number of results was adjusted by this percentage and reported as "Web hits."

\section{Appendix 2 - LexisNexis Search for Media Mentions}

We used the LexisNexis Academic Universe News files on February 24, 2002. Under "general news" we searched the "major newspapers" and "magazines \& journals" files; under "transcripts" we searched "all transcripts." Each search covered the previous five years. We used the "guided search," entering the subject's $<$ firstname lastname $>$ OR $<$ firstname middleinitial lastname $>$ for a full text search. The number of documents found in each case was recorded, and all were examined to determine the number that pertained to the subject of the search. The resultant number is reported as "media mentions." 


$\begin{array}{llll} & \text { ISI } & \text { Web } & \text { LexisNexis } \\ \text { Varian } & 673 & 18520 & 310 \\ \text { Belkin } & 440 & 1004 & 0 \\ \text { Saracevic } & 425 & 861 & 1 \\ \text { Marchionini } & 366 & 2150 & 2 \\ \text { Cronin } & 350 & 1548 & 20 \\ \text { Bates } & 338 & 968 & 2 \\ \text { Borgman } & 336 & 2028 & 6 \\ \text { McClure } & 316 & 3402 & 4 \\ \text { Hernon } & 276 & 2112 & 3 \\ \text { Kuhlthau } & 253 & 1075 & 1 \\ \text { Drabenstott } & 241 & 641 & 2 \\ \text { Buckland } & 235 & 1952 & 2 \\ \text { Fidel } & 204 & 1030 & 1 \\ \text { Tenopir } & 201 & 1540 & 19 \\ \text { Kling } & 196 & 4630 & 9 \\ \text { Harter } & 182 & 913 & 0 \\ \text { White } & 156 & 924 & 0 \\ \text { Spink } & 154 & 985 & 5 \\ \text { Schamber } & 140 & 389 & 0 \\ \text { Allen } & 123 & 414 & 0 \\ \text { Van House } & 121 & 123 & 6 \\ \text { Losee } & 110 & 659 & 0 \\ \text { Budd } & 106 & 779 & 0 \\ \text { Kantor } & 102 & 804 & 0 \\ \text { Larson } & 102 & 1244 & 0\end{array}$

Table 1. Citation counts, Web hits, and media mentions 


$\begin{array}{llll} & \text { ISI } & \text { Web } & \text { LexisNexis } \\ \text { Varian } & 1 & 1 & 1 \\ \text { Belkin } & 2 & 13 & 17 \\ \text { Saracevic } & 3 & 18 & 14 \\ \text { Marchionini } & 4 & 4 & 10 \\ \text { Cronin } & 5 & 8 & 2 \\ \text { Bates } & 6 & 15 & 10 \\ \text { Borgman } & 7 & 6 & 5 \\ \text { McClure } & 8 & 3 & 8 \\ \text { Hernon } & 9 & 5 & 9 \\ \text { Kuhlthau } & 10 & 11 & 14 \\ \text { Drabenstott } & 11 & 22 & 10 \\ \text { Buckland } & 12 & 7 & 10 \\ \text { Fidel } & 13 & 12 & 14 \\ \text { Tenopir } & 14 & 9 & 3 \\ \text { Kling } & 15 & 2 & 4 \\ \text { Harter } & 16 & 17 & 17 \\ \text { White } & 17 & 16 & 17 \\ \text { Spink } & 18 & 14 & 7 \\ \text { Schamber } & 19 & 24 & 17 \\ \text { Allen } & 20 & 23 & 17 \\ \text { Van House } & 21 & 25 & 5 \\ \text { Losee } & 22 & 21 & 17 \\ \text { Budd } & 23 & 20 & 17 \\ \text { Kantor } & 24 & 19 & 17 \\ \text { Larson } & 24 & 10 & 17\end{array}$

Table 2. Rankings by citation counts, Web hits, and media mentions 


$\begin{array}{llll} & \text { ISI } & \text { Web } & \text { LexisNexis } \\ \text { ISI } & 1 & & \\ \text { Web } & 0.687805 & 1 & \\ \text { LexisNexis } & 0.661038 & 0.965838 & 1\end{array}$

Table 3. Correlations of citation counts, Web hits, and media mentions 